\title{
Molecular characterization of an anther-specific gene from tobacco shows sequence similarity to a tapetum-specific gene from tomato
}

\begin{abstract}
We have cloned and determined the DNA sequence of the cDNA of $n t G R P 15$. The cDNA $n t G R P 15$ represents an anther-specific, developmentally regulated gene from Nicotiana tabacum that encodes a glycinerich protein. Northern analysis shows that the gene is specifically expressed in anthers and is stringently regulated during anther development. It appears only in anthers at the meiosis to free microspore stages of development. The encoded protein is small $(12.2 \mathrm{kDa})$, has a $31 \%$ glycine content and contains a putative signal sequence. By both nucleotide and amino acid sequence alignment, the gene shows high sequence similarity to a gene previously isolated from Lycopersicon esculentum, namely, TomA92b9. High glycine content, presence of a signal sequence and similarity to the tomato TomA92b9 gene suggests the protein functions as a structural cell wall protein, possibly involved in pollen exine formation.
\end{abstract}

Key words Glycine-rich · Tobacco · Tomato Pollen development $\cdot$ Signal sequence

Pollen formation is an elaborate process dependent on the accurate interplay of the developmental programs of sporophytic and gametophytic tissues in the anther. Several researchers have isolated and characterized antherspecific genes in attempts to understand the molecular

This is publication number 981210040 of the Minnesota Agricultural Experiment Station. The tobacco and tomato sequences are listed in GenBank under the following accession numbers: tobacco ntGRP15 U74325, tomato TomA92b9 Z21719.

S.I. Fuerstenberg $(\bullet)$

Biology Department, University of Michigan,

830 N. University Ave. Ann Arbor, MI 48109, USA

e-mail: sifuerst@umich.edu

Fax: +1-734-647-0884

P.B. Bucciaglia · A.G. Smith

Department of Horticultural Science, University of Minnesota, 305 Alderman Hall, St. Paul, MN 55108, USA mechanisms underlying pollen development (reviewed in Schrauwen et al. 1996). These genes can be grouped by function into those whose encoded proteins: (1) are thought to be lipid transfer proteins such as TomA5b (Aguirre and Smith 1993) and $e 2$ (Foster et al. 1992); (2) are components of the exine wall including TA29 (Seurinck et al. 1990; Koltunow et al. 1990) and TomA92b9 (Chen et al. 1994); (3) are callases such as Tagl (Bucciaglia and Smith 1994) and a6 (Hird et al. 1993) or (4) are proteins of unknown function such as tap1 and tap2 (Nacken et al. 1991a,b) and MSF14 (Wright et al. 1993). Our knowledge is as yet incomplete and the isolation and characterization of additional anther- and tapetum-specific genes will aid in the delineation of the molecular programs necessary for pollen development.

Here we report the isolation and characterizaton of an anther-specific gene from tobacco, $n t G R P 15$. It is expressed only in anthers from meiosis to the early free microspore stages of development. It encodes a small, glycine-rich protein indicating a structural rather than enzymatic role in the anther (Schrauwen et al. 1996; Koltunow et al. 1990). The encoded protein contains an N-terminal signal peptide necessary for entrance into the secretory pathway (von Heijne 1985). There is high nucleotide sequence similarity to TomA92b9, a tomato gene specifically localized to the tapetum (Chen et al. 1994) and thought to be involved in pollen exine formation.

Nicotiana tabacum L. cv. Samsun plants were grown and the flowers developmentally staged as in Bucciaglia and Smith (1994). RNA was extracted from buds, pistils, anthers, and leaves according to Rochester et al. 1986. Poly(A)-enriched RNA was extracted and used to synthesize the first strand cDNA. PCR reactions were done using sense primer: 5'-CGGGATCCGGNGTNTGYTAYGG-3' and antisense primer: 5'-CGGAATTCGGCCANCCNSWYTC-3' (where $\mathrm{N}=\mathrm{A}, \mathrm{C}, \mathrm{G}$ or $\mathrm{T}$; $\mathrm{R}=\mathrm{A}$ or $\mathrm{G}$; $\mathrm{Y}=\mathrm{C}$ or $\mathrm{T} ; \mathrm{S}=\mathrm{C}$ or $\mathrm{G}$ and $\mathrm{W}=\mathrm{A}$ or $\mathrm{T}$ ) as previously described (Bucciaglia and Smith 1994). The PCR reaction yielded a 245-bp fragment that was cloned into pBluescript SK(- and +) vectors (Stratagene). This cloned frag- 
Fig. 1 Alignment of the amino acid sequences of $n t G R P 15$ and TomA92b9. Vertical lines indicate amino acid identity between the two proteins. Dashes indicate gaps relative to the TomA92b9 protein sequence. The asterisk marks the putative signal sequence cleavage sites in both $n t G R P 15$ and TomA92b9

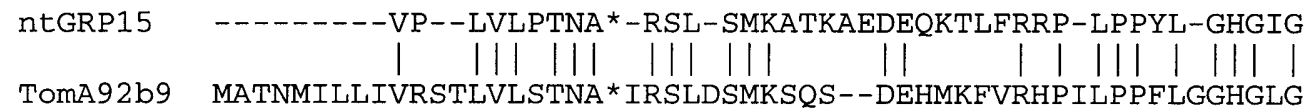

ntGRP15

TomA92b9

RPGFGVGP--GFG--SG-VGGGFGNNPFGGISS-------GSGLGFGAGTG- - || |||| ||| | || || || ||||||

RPRFGVGPVIGFGPFGGIVGGVGPNNG-GGLGFGTGTGTDNGSGLGFGTEIGSGSN
ntGRP15

TomA92b9
FGSSIGGAGGFGSG-V--GGF-GDD-GGSSSNGNGVFAGGQGEGDDAAIGNQKP

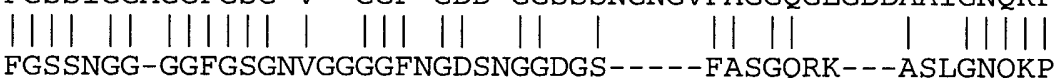

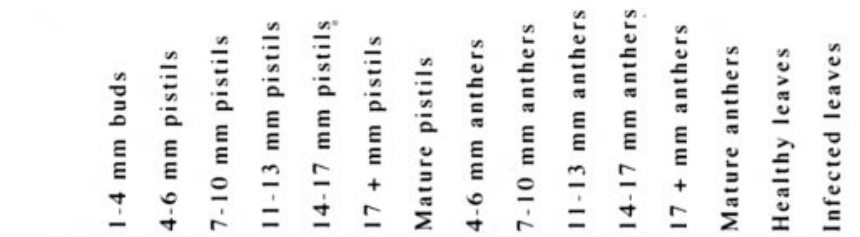

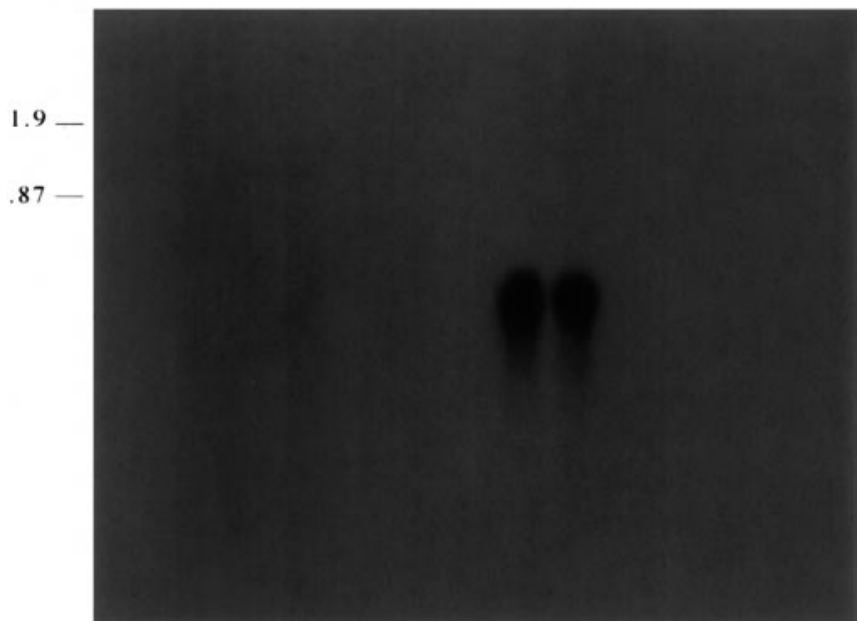

Fig. 2 Northern blot analysis of $n t G R P 15$ mRNA in tobacco. Each lane contains $20 \mu \mathrm{g}$ of total RNA from: buds $1-4 \mathrm{~mm}$ in length; pistils or anthers from flowers 4-6, 7-10, 11-13, 14-17, and greater than $17 \mathrm{~mm}$ in length; mature pistils and mature anthers from flowers whose anthers were dehiscent; healthy leaves and leaves infected with TMV. The RNA was hybridized with the 32P-labeled $n t G R P 15$ 245-bp PCR fragment and exposed to film for 7 days. RNA size standards in $\mathrm{kb}$ are shown to the left

ment was used as a probe in northern analysis and to isolate the 621-bp ntGRP15 from a tobacco cDNA library.

Flowers greater than $4 \mathrm{~mm}$ in length were chosen whose corresponding anthers were developmentally premeiotic to dehiscent (4-6 $\mathrm{mm}$ : premeiotic, 7-10 mm: meiotic, 11-13 mm: early free microspore, 14-17: late free microspore, $>17 \mathrm{~mm}$ : microspore mitosis, mature: dehiscent). Pistils were isolated from these staged flowers. Buds 1-4 mm in length, healthy leaves, and leaves infected with TMV (tobacco mosaic virus) were also sampled. Northern blot analysis was done as described in Bucciaglia and Smith (1994).

The nucleotide sequence of the $n t G R P 15$ cDNA isolated from the tobacco anther library was determined in both directions (Sanger et al. 1977) using a Sequenase 2.0 sequencing kit (U.S. Biochemical). Computer analysis of the nucleotide and inferred amino acid sequences were performed using the GCG software package. These sequences were used in BLAST searches (NCBI BLAST - Altschul et al. 1990; Altschul et al. 1997) of nucleotide and protein databases.

A Blastn (nucleotide) search identified TomA92b9 cDNA as the nucleotide sequence with the highest sequence similarity to $n t G R P 15$. An alignment of the two nucleotide sequences exhibits 58\% nucleotide sequence identity (data not shown). The protein encoded by $n t G R P 15$ is 129 amino acids in length and contains $31 \%$ glycine residues (Fig. 1). There is a putative signal cleavage site between residues 9 and 10 (von Heijne 1985). The mature protein has a mass of $11.4 \mathrm{kDa}$. Analysis of the protein sequence indicates no ER retention signals exist in the C-terminus of the putative peptide (Hesse et al. 1989; Denecke et al. 1992). A Blastp search of protein databases retrieved several very large glycinerich proteins whose sequences were aligned to $n t G R P 15$ solely by high glycine content. Manual alignment of the 20 highest scoring proteins in the Blastp search found that TomA92b9 had the highest overall amino acid sequence identity, $49 \%$.

It should be noted that the $n t G R P 15$ probe hybridizes to a fragment of approximately $700 \mathrm{nt}$. The length of the sequenced $n t G R P 15$ clone (621 bp), the alignment of $n t G R P 15$ with TomA92b9 and the typical length of eukaryotic signal sequences (von Heijne 1985) indicate that the cloned $n t G R P 15$ is approximately a full length cDNA.

Northern analysis shows that ntGRP15 RNA is expressed only in 7-10 $\mathrm{mm}$ anthers and $11-13 \mathrm{~mm}$ flowers (Fig. 2). Anthers in 7-10 mm tobacco flowers have a fully differentiated tapetum and a pollen sac which contains microspore mother cells undergoing meiosis. Callose walls form between the microspore mother cells in anthers of 6-7 $\mathrm{mm}$ flowers and microspores are in tetrads by the 10-11 $\mathrm{mm}$ stage. At 12-13 mm, the callose wall has been degraded and the microspores released into the locule. At stages $14 \mathrm{~mm}$ and beyond, the tapetum begins to shrink and then degenerates (Bucciaglia and Smith 1994; Koltunow et al. 1990). At the stages of anther development in which $n t G R P 15$ is expressed, the tapetum is actively producing materials that, when secreted, form the outer pollen wall. 
The $n t G R P 15$ gene encodes a protein with features that allude to its function. The mature protein is small, 11.4 $\mathrm{kDa}$, based on the cDNA sequence. Such a small protein is unlikely to have an enzymatic function (Schrauwen et al. 1996). Its high glycine content suggests that the protein may serve in a structural capacity. The presence of an Nterminal signal peptide indicates the protein is secreted. The lack of any ER retention signals (Hesse et al. 1989; Denecke et al. 1992) indicates that the protein is not retained in the ER. There is substantial nucleotide and amino acid similarity to TomA92b9, a gene whose expression is tapetal-specific. Both genes are expressed during meiosis through free microspore stages of anther development (Chen et al. 1994). The proteins are of similar small size $(<15 \mathrm{kDa})$ and both contain a putative signal peptide with conserved residues surrounding the cleavage site (Fig. 1). The glycine content is similar between the two mature proteins (TomA92b9 27.9\% and $n t G R P 1531 \%$ ). Based on the features of the $n t G R P 15$ protein and its similarity to TomA92b9, it seems possible that $n t G R P 15$ encodes a pollen wall protein that is synthesized in the tapetum and secreted to the developing microspores.

Acknowledgements Thanks to Jeffrey Boore, Kevin Helfenbein and Alan Wolf for critical review of this manuscript.

\section{References}

Aguirre PJ, Smith AG (1993) Molecular characterization of a gene encoding a cysteine-rich protein preferentially expressed in anthers of Lycopersicon esculentum. Plant Mol Biol 23: 477-487

Altschul SF, Gish W, Miller W, Myers W, Lipman DJ (1990) Basic local alignment search tool. J Mol Biol 215:403-410

Altschul SF, Madden TL, Schäffer A, Zhang J, Zhang Z, Miller W, Lipman DJ (1997) Gapped BLAST and PSI-BLAST: a new generation of protein database search programs. Nucleic Acids Res 25:3389-3402

Bucciaglia PA, Smith AG (1994) Cloning and characterization of Tag 1, a tobacco anther $\beta$-1, 3-glucanase expressed during tetrad dissolution. Plant Mol Biol 24:903-914
Chen R, Aguirre PJ, Smith AG (1994) Characterization of an anther- and tapetum-specific gene encoding a glycine-rich protein from tomato. J Plant Physiol 143:651-658

Denecke J, Rycke R, Botterman J (1992) Mammalian- and plantsorting signals for protein retention in the endoplasmic reticulum form a closely related epitope. EMBO J 11:2345-2355

Foster GD, Robinson SW, Blundell RP, Roberts MR, Hodge R, Draper J, Scott RJA (1992) Brassica napus mRNA encoding a protein homologous to phospholipid transfer proteins is expressed specifically in the tapetum and developing microspores. Plant Sci 84:187-192

Heijne G von (1985) Signal sequences: the limits of variation. J Mol Biol 184:99-105

Hesse T, Feldswisch J, Balshüsemann D, Bauw G, Puype M, Vandercklov J, Löbler M, Klämbt D, Schell J, Palme K (1989) Molecular cloning and structural analysis of a gene from Zea mays $\mathrm{L}$ coding for a putative receptor for the plant hormone auxin. EMBO J 11:2453-2461

Hird DL, Worrall D, Hodge R, Smartt S, Wyatt P, Scott R (1993) The anther-specific protein encoded by the Brassica napus and Arabidopsis thaliana a6 gene displays similarity to $\beta$-13-glucanases. Plant J 4:1023-1033

Koltunow AM, Truettner J, Cox KH, Wallroth M, Goldberg RB (1990) Different temporal and spatial gene expression patterns occur during anther development. Plant Cell 2:1201-1224

Nacken WKF, Huijser P, Beltran H-P, Saedler H, Sommer H (1991a) Molecular characterization of two stamen-specific genes tapl and fill that are expressed in the wild type but not the deficiens mutant of Antirrhinum majus. Mol Gen Genet 229:129-136

Nacken WKF, Huijser P, Saedler H, Sommer H (1991b) Molecular analysis of tap2 an anther-specific gene from Antirrhinum majus. FEBS Lett 280:155-158

Rochester DE, Winter JA, Shah DM (1986) The structure and expression of maize genes encoding the major heat shock protein hsp70. EMBO J 5:451-458

Sanger F, Nicklen S, Coulson AR (1977) DNA sequencing with chain terminating inhibitors. Proc Natl Acad Sci USA 74: 5463-5467

Schrauwen JAM, Mettenmeyer T, Croes AF, Wullems GJ (1996) Tapetum-specific genes: what role do they play in male gametophyte development? Acta Bot Neerl 45:1-15

Seurinck J, Truettner J, and Goldberg RB (1990) The nucleotide sequence of an anther-specific gene Nucleic Acids Res 18: 3403

Wright SY, Suner M-M, Bell PJ, Vaudin M, Greenland AJ (1993) Isolation and characterization of male flower cDNAs from maize. Plant J 3:41-49 